\title{
Deep learning v psychoterapii: Strojová analýza nahrávek terapeutických sezení
}

\author{
Tomáš Řiháček a Pavel Matějka
}

Psychoterapie je profese charakteristická nedostatkem bezprostřední zpětné vazby o účinnosti odborných intervencí. Psychoterapeuti jsou z velké části odkázáni na svůj klinický úsudek a intuici. Výzkum přitom ukazuje, že terapeuti mají tendenci nadhodnocovat své dovednosti a míru úspěšnosti (Walfish et al., 2012), jen obtížně rozpoznávají a předvídají zhoršení klientů (Hannan et al., 2005; Hatfield et al., 2010), a s přibývající praxí se ve své práci nejen nezlepšují, ale mají dokonce tendenci se mírně zhoršovat (Goldberg et al., 2016). Možné řešení nabízí systematická zpětná vazba, která terapeutům umožní získat objektivnější pohled na účinnost jejich intervencí (např. de Jong et al., 2021; Shimokawa et al., 2010).

Za tímto účelem vyvíjí tým pracovníků Vysokého učení technického v Brně a Masarykovy univerzity webovou aplikaci, jejímž cílem je poskytovat terapeutům zpětnou vazbu na základě automatického zpracování pravidelně získávaných dotazníkových dat a audionahrávek z terapeutických sezení. Na projektu dále spolupracují psychoterapeuti Psychosomatické kliniky, s.r.o., a Terapeutického př́istavu, z.ú., kteří průběžně vyvíjenou aplikaci ověřují v praxi a poskytují cennou zpětnou vazbu a náměty $\mathrm{k}$ jejím funkcím. Projekt je spolufinancován se státní podporou Technologické agentury ČR v rámci Programu ÉTA (grant č. TL03000049).

Plánované funkce, kterými by měla aplikace po dokončení vývoje disponovat, zahrnují:

- Sběr a automatické vyhodnocení dotazníkových dat;

- Automatický přepis audiozáznamů terapeutických sezení;

- Extrakce akustických a lingvistických parametrů řeči;

- Klasifikace terapeutových intervencí a klientových reakcí;

- Vizualizace vybraných parametrů;

- Individualizovaná predikce vývoje terapeutických př́ípadů.

Některé funkce, např. dotazníkové měření a zpětná vazba, sledují osvědčenou praxi monitorování výsledků psychoterapie v západních zemích (Řiháček \& Juhová, 2016). Jiné, např. automatizovaná klasifikace terapeutových intervencí, jsou experimentální a úspěšnost jejich vývoje závisí na řadě mezikroků, jakými jsou dostatečně přesný přepis terapeutického rozhovoru či dostatečná spolehlivost strojové klasifikace terapeutových a klientových promluv. Při vývoji aplikace budeme využívat (a zároveň dále rozvíjet) poznatky o automatickém rozpoznávání řeči a jeho adaptaci na řečníka $\mathrm{v}$ psychoterapeutickém kontextu, a dále techniky zpracování přirozeného jazyka a strojového učení. Zatímco některé proměnné je možno extrahovat automaticky, jiné se bude aplikace „učit“ rozpoznávat pomocí tzv. supervidovaného učení. 
Vývojem aplikace sledujeme dva vzájemně provázané cíle. Prvním z nich je zkvalitnění práce psychoterapeutů: Při minimální časové investici získají terapeuti další zdroj cenných informací o průběhu terapeutického procesu a změnách na straně klienta, které mohou využít při tvorbě svého klinického úsudku a dalším plánování terapie. Součástí tohoto cíle je též plánovaná podpora terapeutů a institucí při implementaci aplikace do běžné praxe. Druhým cílem je kumulace bohatých dat o průběhu a výsledcích psychoterapie, která v dlouhodobém horizontu přispějí k lepšímu porozumění procesu a zákonitostem terapeutické změny a pomohou aplikaci dále vyvíjet.

Při vývoji a provozu aplikace klademe důraz na adekvátní zabezpečení a ochranu citlivých dat. Projekt byl schválen Etickou komisí pro výzkum Masarykovy univerzity (ref. č. EKV-2019079-R1). Pracovní verze aplikace je již nyní dostupná na adrese https://deepsy.cz.

$\mathrm{Na}$ řešení projektu se kromě autorů příspěvku podílejí za Vysoké učení technické v Brně Karel Beneš, Martin Karafiát, Ondřej Novotný a Josef Žižka, za Masarykovu univerzitu Michal Čevelíček, Michaela Ladmanová, Štěpánka Loulová, Jan Nehyba a Petr Sojka, za Psychosomatickou kliniku, s.r.o., Jaromír Kabát a Radim Karpíšek a za Terapeutický př́stav, z.ú., Tomáš Novotný a Daniel Wagner.

\section{Literatura}

de Jong, K., Conijn, J. M., Gallagher, R. A. V., Reshetnikova, A. S., Heij, M., \& Lutz, M. C. (2021). Using progress feedback to improve outcomes and reduce drop-out, treatment duration, and deterioration: A multilevel meta-analysis. Clinical Psychology Review, 85, 1-19. https://doi.org/10.1016/j.cpr.2021.102002

Goldberg, S. B., Rousmaniere, T., Miller, S. D., Whipple, J., Nielsen, S. L., Hoyt, W. T., \& Wampold, B. E. (2016). Do psychotherapists improve with time and experience? A longitudinal analysis of outcomes in a clinical setting. Journal of Counseling Psychology, 63(1), 1-11. https://doi.org/10.1037/cou0000131

Hannan, C., Lambert, M. J., Harmon, C., Nielsen, S. L., Smart, D. W., Shimokawa, K., \& Sutton, S. W. (2005). A lab test and algorithms for identifying clients at risk for treatment failure. Journal of Clinical Psychology, 61(2), 155-163. https://doi.org/10.1002/jclp.20108

Hatfield, D., McCullough, L., Frantz, S. H. B., \& Krieger, K. (2010). Do we know when our clients get worse? An investigation of therapists' ability to detect negative client change. Clinical Psychology and Psychotherapy, 17(1), 25-32. https://doi.org/10.1002/cpp.656

Řiháček, T., \& Juhová, D. (2016). Monitorování účinnosti v psychoterapii a poradenství. Testforum, 7, 1-13. https://doi.org/10.5817/TF2016-7-99

Shimokawa, K., Lambert, M. J., \& Smart, D. W. (2010). Enhancing treatment outcome of patients at risk of treatment failure: Meta-analytic and mega-analytic review of a psychotherapy quality assurance system. Journal of Consulting and Clinical Psychology, 78(3), 298-311. https://doi:org/10.1037/a0019247 
Walfish, S., McAlister, B., O’Donnell, P., \& Lambert, M. J. (2012). An investigation of selfassessment bias in mental health providers. Psychological Reports, 110(2), 639-644. https://doi.org/10.2466/02.07.17.PR0.110.2.639-644

\section{Kontakt na řešitele projektu:}

Pavel Matějka (hlavní řešitel)

Adresa: Fakulta informačních technologií, Vysoké učení technické v Brně, Božetěchova 2, 61266 Brno

E-mail: matejkap@fit.vutbr.cz

Tomáš Řiháček (spoluřešitel)

Adresa: Fakulta sociálních studií, Masarykova univerzita, Joštova 10, 60200 Brno E-mail: rihacek@fss.muni.cz

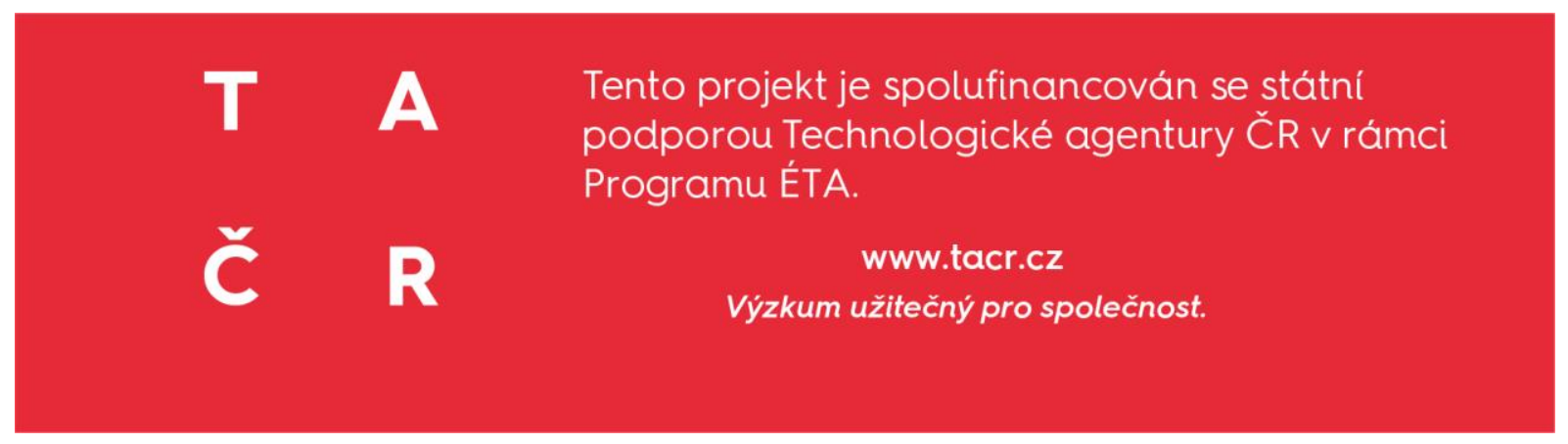

К̌iháček, T., \& Matějka, P. (2021). Deep learning v psychoterapii: Strojová analýza nahrávek terapeutických sezení. E-psychologie, 15(3), 35-37. https://doi.org/10.29364/epsy.414 